\title{
Article \\ EWAS of Monozygotic Twins Implicate a Role of mTOR Pathway in Pathogenesis of Tic Spectrum Disorder
}

\author{
Mathis Hildonen ${ }^{1}{ }^{\oplus}$, Amanda M. Levy ${ }^{1}{ }^{\circledR}$, Christine Søholm Hansen ${ }^{2}$, Jonas Bybjerg-Grauholm ${ }^{2}$, Axel Skytthe ${ }^{3}$, \\ Nanette M. Debes ${ }^{4}$, Qihua Tan ${ }^{3,5}$ and Zeynep Tümer ${ }^{1,6, *(D)}$ \\ 1 Kennedy Center, Department of Clinical Genetics, Copenhagen University Hospital, Rigshospitalet, \\ 2600 Glostrup, Denmark; mathis.hildonen@regionh.dk (M.H.); marie.amanda.bust.levy@regionh.dk (A.M.L.) \\ 2 Department for Congenital Disorders, Statens Serum Institut, 2300 Copenhagen, Denmark; \\ chsh@ssi.dk (C.S.H.); jogr@ssi.dk (J.B.-G.) \\ 3 Epidemiology and Biostatistics, Department of Public Health, University of Southern Denmark, \\ 5000 Odense, Denmark; askytthe@health.sdu.dk (A.S.); qtan@health.sdu.dk (Q.T.) \\ 4 Tourette Clinics, Department of Paediatrics, Copenhagen University Hospital, 2730 Herlev, Denmark; \\ nanette.marinette.monique.debes@regionh.dk \\ 5 Unit of Human Genetics, Department of Clinical Research, University of Southern Denmark, \\ 5000 Odense, Denmark \\ 6 Department of Clinical Medicine, Faculty of Health and Medical Sciences, University of Copenhagen, \\ 2200 Copenhagen, Denmark \\ * Correspondence: zeynep.tumer@regionh.dk
}

\section{check for} updates

Citation: Hildonen, M.; Levy, A.M.; Hansen, C.S.; Bybjerg-Grauholm, J.; Skytthe, A.; Debes, N.M.; Tan, Q.; Tümer, Z. EWAS of Monozygotic Twins Implicate a Role of mTOR Pathway in Pathogenesis of Tic Spectrum Disorder. Genes 2021, 12, 1510. https://doi.org/10.3390/ genes12101510

Academic Editor: Erin (Eun-Young) Ahn

Received: 15 July 2021

Accepted: 23 September 2021

Published: 26 September 2021

Publisher's Note: MDPI stays neutral with regard to jurisdictional claims in published maps and institutional affiliations.

Copyright: (c) 2021 by the authors. Licensee MDPI, Basel, Switzerland. This article is an open access article distributed under the terms and conditions of the Creative Commons Attribution (CC BY) license (https:// creativecommons.org/licenses/by/ $4.0 /)$.

\begin{abstract}
Tic spectrum disorder (TSD) is an umbrella term which includes Gilles de la Tourette syndrome (GTS) and chronic tic disorder (CTD). They are considered highly heritable, yet the genetic components remain largely unknown. In this study we aimed to investigate disease-associated DNA methylation differences to identify genes and pathways which may be implicated in TSD aetiology. For this purpose, we performed an exploratory analysis of the genome-wide DNA methylation patterns in whole blood samples of 16 monozygotic twin pairs, of which eight were discordant and six concordant for TSD, while two pairs were asymptomatic. Although no sites reached genome-wide significance, we identified several sites and regions with a suggestive significance, which were located within or in the vicinity of genes with biological functions associated with neuropsychiatric disorders. The two top genes identified (TSC1 and CRYZ/TYW3) and the enriched pathways and components (phosphoinosides and PTEN pathways, and insulin receptor substrate binding) are related to, or have been associated with, the PI3K/AKT/mTOR pathway. Genes in this pathway have previously been associated with GTS, and mTOR signalling has been implicated in a range of neuropsychiatric disorders. It is thus possible that altered mTOR signalling plays a role in the complex pathogenesis of TSD.
\end{abstract}

Keywords: Gilles de la Tourette syndrome; GTS; tics; methylation; epigenetics; TSC1; mTOR; monozygotic twins; chronic tic disorder; tic spectrum disorder

\section{Introduction}

Gilles de la Tourette syndrome (GTS) is characterized by the presence of at least one vocal and two motor tics, while chronic tic disorder (CTD) is characterized by the presence of either vocal or motor tics. Both GTS and CTD are neurodevelopmental disorders with childhood onset (before the age of 18). There is currently no clinical or genetic evidence suggesting that GTS and CTD are separate disorders, and the term tic spectrum disorder (TSD) has been proposed to replace GTS and CTD [1]. For some individuals the symptoms cease as they progress into adulthood. A high proportion of individuals with TSD have comorbid disorders, including attention deficit-hyperactivity disorder (ADHD), obsessivecompulsive disorder (OCD) and autism spectrum disorder (ASD) [1-3]. 
TSD is a complex disorder with a largely unknown aetiology, where multiple genes are hypothesized to interact with a range of environmental risk factors. The results of heritability studies suggest genetic risk factors play a substantial role in pathogenesis [4,5], but identification of TSD-associated susceptibility genes has been challenging, likely due to a complex and heterogeneous genetic architecture [6-8]. The limited success of the genetic studies can be due to technical issues, such as small sample sizes or incomplete phenotyping of the cohorts, but it is plausible that TSD pathogenesis may be triggered by environmentally mediated epigenetic changes, which may affect gene expression, leading to phenotypic alterations. To date, only two targeted DNA methylation studies of candidate GTS genes has been performed and both studies investigated DNA isolated from peripheral blood lymphocytes. The study carried out by Müller-Vahl and colleagues showed a negative correlation between methylation of the dopamine transporter gene (SLC6A3) and tic severity, while higher methylation levels of the dopamine D2 receptor gene (DRD2) were associated with GTS and positively correlated with tic severity [9]. The other study carried out by our group did not reveal any differences in methylation levels of the serotonin transporter gene (SLC6A4) in GTS individuals compared to controls [10].

Studying epigenetic changes is more challenging compared to genomic alterations. Monozygotic (MZ) twin studies can be advantageous to traditional case-control studies, due to the fact that MZ-twins are matched for not only genotype, sex, age and maternal environment, but also partially matched for early environmental influences. As these factors are shown or hypothesized to influence DNA methylation and therefore gene expression, MZ-twin design has a unique advantage [11]. Previously, a single epigenomewide association study (EWAS) was undertaken in individuals with self-reported tics/tic disorders without reaching a genome-wide significance [12]; however, this study was not designed as a clinical twin-study. In this study, we aimed to investigate disease-associated DNA methylation differences to identify genes and pathways which may be implicated in TSD aetiology. For this purpose, we performed an epigenome wide methylation study in blood lymphocytes of 16 clinically well-defined monozygotic twins, concordant, discordant or asymptomatic for TSD.

\section{Materials and Methods}

\subsection{Individuals, Phenotyping and Zygosity Studies}

Through cross-linking The Danish Psychiatric Central Register and The Danish Twin Register we identified 204 twin pairs, where at least one twin had GTS or CTD (Collectively referred to as TSD throughout the manuscript). All the twins or legal guardians were contacted, and 56 twin pairs accepted to participate. DNA was isolated from peripheral blood and the zygosity of the twins was determined with SNP genotyping using Infinium Global Screening Array (llumina). Fourteen twin pairs were monozygotic. Interviews were carried out with all the twins and a trained neuropediatrician made the diagnosis using the DSM-V (Diagnostic and Statistical Manual of Mental Disorders-V) criteria. Eight of these pairs were discordant for TSD and six were concordant. Furthermore, two asymptomatic MZ twin pairs were included in the study. The study was approved by the Danish Institutional Review Board (2011 H-2-2010-144).

\subsection{DNA Methylation Profiling and Quality Control}

Genomic DNA was extracted from peripheral blood and bisulfite treatment was carried out using standard protocols. Infinium MethylationEPIC arrays (Illumina, San Diego, CA, USA) were used to analyse the bisulfite converted DNA according to manufacturer's protocol. A detection $p$-value for quality control (QC) was calculated using the free $\mathrm{R}$ package minfi [13]. Probes with detection $p>0.01$, probes on sex chromosomes, probes harbouring single nucleotide polymorphisms (SNPs) and probes with known cross-reactivity were excluded from the analysis. After QC, 756,887 probes remained for analysis. Quantile normalization implemented in the $\mathrm{R}$ package minfi was used for data normalisation. $\beta$ values defined by Illumina's formula as $\beta=M /(M+U)$ was used to quantify DNA methy- 
lation levels (M, methylated and $\mathrm{U}$, unmethylated signal intensities at each $\mathrm{CpG}$ site). To conduct statistical analysis methylation $\beta$ values were logit transformed to $M$ values.

\subsection{Statistical Analyses}

The DNA used in this study was extracted from whole blood, which contains several different types of blood cells. As different cell types are known to have different methylation patterns, the R package FlowSorted.Blood.EPIC [14] was used to estimate the proportion of CD4T, CD8T, NK cells, B cells, monocytes and neutrophils in each sample. The MannWhitney U-test was used to compare the cell type composition between TSD individuals and controls.

A linear mixed model using the R package lmerTest [15], regressing methylation levels on clinical phenotype was employed to identify differentially methylated positions (DMPs) associated with TSD. The model was corrected for age, with twin pairing as a random effect. As we did not observe any difference in cell-type composition between TSD individuals and controls (Supplementary Figure S1), and as our sample size was relatively small, we did not include cell-type composition in the analysis to avoid overfitting the model. False discovery rate (FDR) was set to $<0.05$ as a cut-off for genome-wide significance to correct for multiple testing. DMPs significantly associated with TSD $(p<0.01)$ were submitted to the Genomic Regions Enrichment of Annotations Tool (GREAT 3.0), an online tool which annotates genomic positions to genes and cis-regulatory elements, and identifies enriched gene ontologies and pathways.

In addition to investigating methylation differences at single sites, we also employed a region-based approach using the python library comb-p [16]. This identifies differentially methylated regions (DMRs) by calculating autocorrelation, combining $p$-values of adjacent sites and assigning significance to the regions identified. We used the results from the linear mixed model, with an unadjusted $p$ of $<1 \times 10^{-3}$ to seed a region, and a maximum distance of $500 \mathrm{bp}$ between the $\mathrm{CpG}$ sites. The region results were corrected for multiple testing using the Šidák correction.

\section{Results}

We did not observe any difference in cell-type composition between TSD individuals and controls (Supplementary Figure S1).

To identify differentially methylated probes in TSD individuals we employed a linear mixed model corrected for age with twin pairing as a random effect. None of the probes reached genome-wide significance defined as FDR $<0.05$. As illustrated in Figure 1, a slight deviation from the expected $p$-values was observed, which could indicate non-random association. Nine sites with suggestive significance $\left(p<1 \times 10^{-5}\right)$ were detected (Table 1 , Figure 2). Three of these sites were located within or close to genes (TSC1, NEMF and $A D A$ ) which were previously implicated in with neuropsychiatric disorders. The DMP most significantly associated with TSD was located in the promoter region of TSC1. 


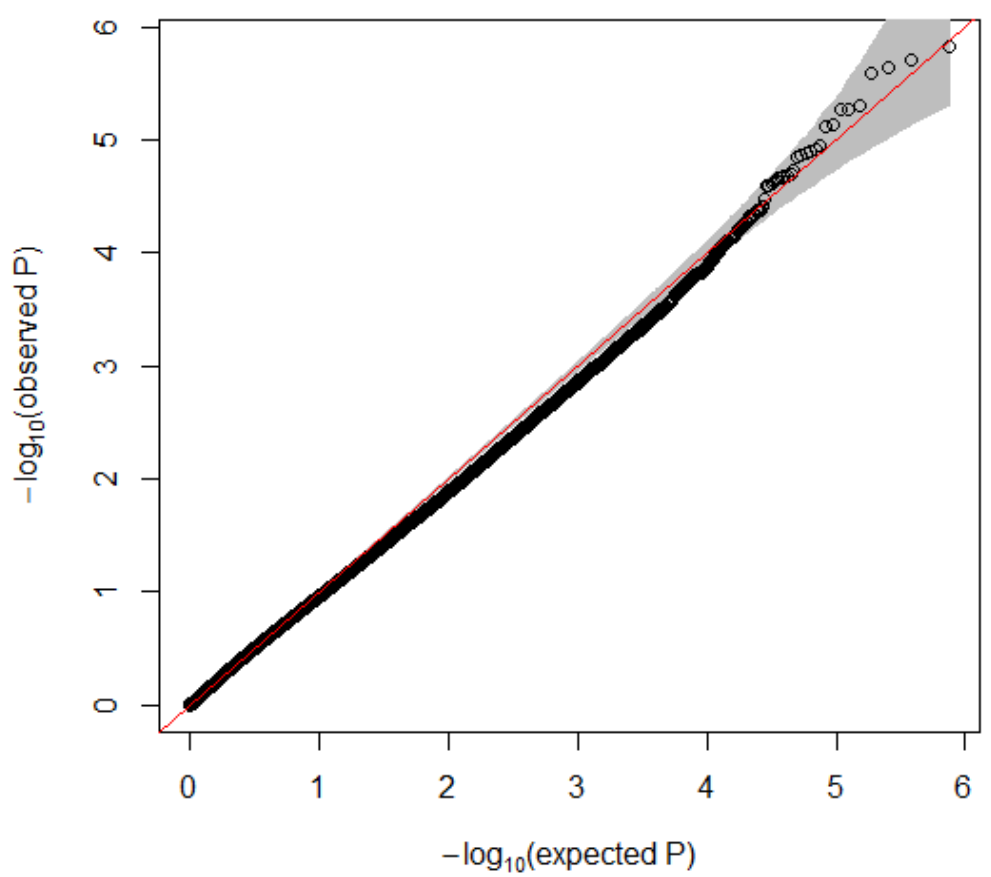

Figure 1. Quantile-quantile plot of expected ( $x$-axis) versus observed ( $y$-axis) $p$-values. At lower $p$-values there is a slight deviation from the expected pattern which may indicate presence of nonrandom association. The circles represent the $\mathrm{CpG}$ sites investigated in this study. The red line indicates the expected pattern if there is no difference between expected and observed $p$-values, and the grey area indicates a confidence interval of $95 \% . \log _{10}$, logarithm base 10 .

Table 1. Differentially methylated positions (DMPs) with a $p$-value $<1 \times 10^{-5}$.

\begin{tabular}{|c|c|c|c|c|c|c|}
\hline Rank & $\begin{array}{c}\text { DMP } \\
\text { (CpG Site) }\end{array}$ & $\begin{array}{l}\text { Chromosome } \\
\text { Position } \\
\text { (GRCh37/hg19) }\end{array}$ & $p$-Value & FDR & Coefficient & Closest Genes (Distance from TSS in $b p$ ) ${ }^{a}$ \\
\hline 1 & $\operatorname{cg} 00425865$ & chr9:135820111 & $1.49 \times 10^{-6}$ & 0.48 & -0.6889 & TSC1 (-104)/GFI1B (-826) \\
\hline 2 & cg16051558 & chr14:50235537 & $1.98 \times 10^{-6}$ & 0.48 & 0.3805 & KLHDC2 (+1212)/NEMF $(+84,383)$ \\
\hline 3 & $\operatorname{cg} 15728744$ & chr1:5917533 & $2.29 \times 10^{-6}$ & 0.48 & 0.5383 & NPHP4 $(+134,997)$ \\
\hline 4 & $\operatorname{cg} 18868182$ & chr10:60086874 & $2.54 \times 10^{-6}$ & 0.48 & 0.1460 & UBE2D1 $(-7860) / C I S D 1(+58,057)$ \\
\hline 5 & $\operatorname{cg} 00703598$ & chr2:88480233 & $4.94 \times 10^{-6}$ & 0.58 & -0.2805 & THNSL2 (+9255)/TEX37 $(-343,935)$ \\
\hline 6 & $\operatorname{cg} 02228383$ & chr20:56934684 & $5.33 \times 10^{-6}$ & 0.58 & 0.5032 & $V A P B(-29,493) / R A B 22 A(+49,933)$ \\
\hline 7 & $\operatorname{cg} 06538333$ & chr16:23445078 & $5.39 \times 10^{-6}$ & 0.58 & -0.6260 & COG7 $(+19,422) /$ SCNN1B $(+131,488)$ \\
\hline 8 & $\operatorname{cg} 08283932$ & chr20:43280707 & $7.36 \times 10^{-6}$ & 0.63 & -0.6783 & $A D A(-325)$ \\
\hline 9 & cg20974961 & chr6:49500569 & $7.54 \times 10^{-6}$ & 0.63 & -0.3322 & GLYATL3 $(+32,899) / R H A G(+103,982)$ \\
\hline
\end{tabular}

The table shows the identified DMPs with a significance level $<1 \times 10^{-5}$, their chromosome position, significance values, coefficient and closest genes. a, ' + ' indicates that the DMP is downstream of the TSS, ' - ' indicates that the DMP is upstream of the TSS; FDR, false discovery rate; TSS, transcription start site.

DMPs associated with TSD $(p<0.01, n=5707)$ were investigated for enrichment of gene ontologies and pathways using GREAT. Genomic positions of 5676 DMPs were annotated to one or more genes and/or cis-regulatory elements, and four gene ontologies and two pathways were found to be enriched (Table 2). The genes identified in the enrichment analysis are listed in Supplementary Table S1. 


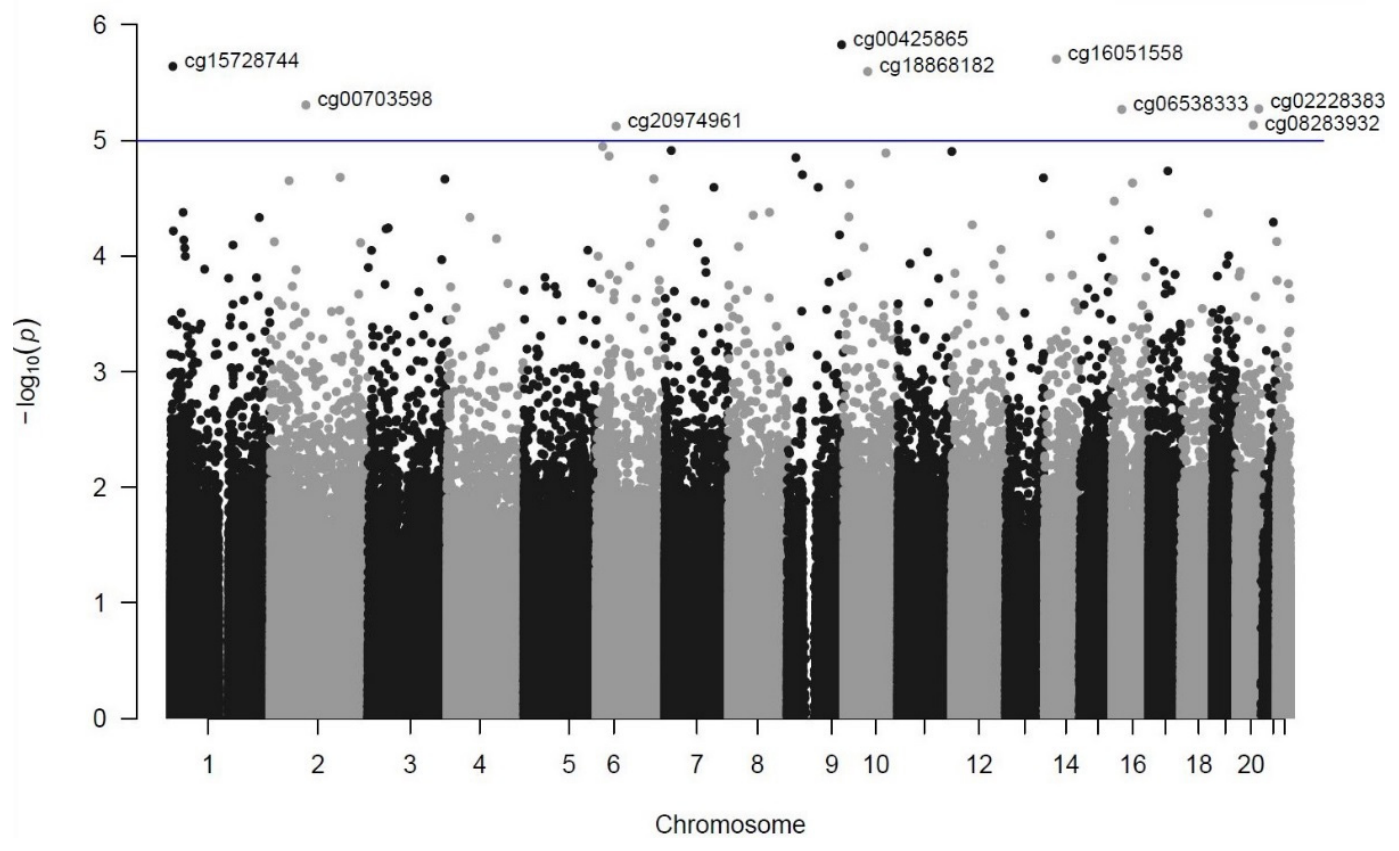

Figure 2. The Manhattan plot shows the $p$-value and chromosomal position of all CpG sites investigated. Each dot represents a CPG site, and the horizontal blue line denotes the threshold $\left(p=1 \times 10^{-5}\right)$ for suggestive significance. Sites with suggestive significance are annotated with Illumina CpG loci ID. Negative logarithm base $10\left(-\log _{10}\right)$ of the $p$ value is shown on the $y$-axis and chromosome positions on the $x$-axis.

Table 2. Enrichment of gene ontologies and pathways among DMPs with $p<0.01$.

\begin{tabular}{|c|c|c|c|c|c|}
\hline Ontology & Term & $\begin{array}{c}\text { Binom Raw } \\
p \text {-Value }\end{array}$ & $\begin{array}{c}\text { Binom FDR } \\
q \text {-Value }\end{array}$ & $\begin{array}{l}\text { Binom Fold } \\
\text { Enrichment }\end{array}$ & $\begin{array}{c}\text { Binom Observed } \\
\text { Region Hits }\end{array}$ \\
\hline GO Cellular Component & $\begin{array}{l}\text { Insulin receptor } \\
\text { substrate binding }\end{array}$ & $3.88 \times 10^{-4}$ & $4.33 \times 10^{-2}$ & 2.25 & 23 \\
\hline \multirow[t]{3}{*}{ GO Biological Process } & $\begin{array}{c}\text { Positive regulation of } \\
\text { hormone metabolic process }\end{array}$ & $9.20 \times 10^{-6}$ & $1.12 \times 10^{-3}$ & 2.70 & 26 \\
\hline & $\begin{array}{c}\text { Positive regulation of } \\
\text { hormone biosynthetic process }\end{array}$ & $1.56 \times 10^{-5}$ & $1.79 \times 10^{-3}$ & 3.08 & 20 \\
\hline & $\begin{array}{l}\text { Regulation of protein } \\
\text { ubiquitination involved in } \\
\text { ubiquitin-dependent protein } \\
\text { catabolic process }\end{array}$ & $5.10 \times 10^{-4}$ & $2.65 \times 10^{-2}$ & 2.36 & 20 \\
\hline \multirow[t]{2}{*}{ MSigDB Pathway } & $\begin{array}{l}\text { Phosphoinositides and their } \\
\text { downstream targets }\end{array}$ & $7.62 \times 10^{-4}$ & $3.14 \times 10^{-2}$ & 2.07 & 25 \\
\hline & $\begin{array}{l}\text { PTEN is a tumor suppressor } \\
\text { that dephosphorylates the } \\
\text { lipid messenger phos- } \\
\text { phatidylinositol triphosphate }\end{array}$ & $1.13 \times 10^{-3}$ & $3.73 \times 10^{-2}$ & 2.39 & 17 \\
\hline
\end{tabular}

The table shows the results of the enrichment analysis of the nominally significant DMPs $(p<0.01)$. Significance levels are reported as binomial raw $p$-values and FDR-adjusted $q$-values. GO, gene ontology; MSigDB, Molecular Signatures Database.

We combined $p$-values of adjacent sites identified by the linear mixed model in the sitespecific analysis to identify differentially methylated genomic regions in TSD individuals compared to controls. Seven regions had three or more CpG sites and a Šidák corrected $p$-value below 0.5. Two regions had a corrected $p$-value below 0.1 (Table 3). 
Table 3. Differentially methylated regions (DMRs) in TSD individuals.

\begin{tabular}{|c|c|c|c|c|c|c|}
\hline Rank & $\begin{array}{l}\text { Chromosome Position } \\
\text { (GRCh37/hg19) }\end{array}$ & $\begin{array}{l}\text { Length } \\
\text { (bp) }\end{array}$ & $\begin{array}{c}\text { No. } \\
\text { of Sites }\end{array}$ & $\begin{array}{l}\text { SLK adj. } \\
p \text {-Value }\end{array}$ & $\begin{array}{l}\text { Šidák adj. } \\
p \text {-Value }\end{array}$ & $\begin{array}{c}\text { Closest Genes } \\
\text { (Distance to TSS) }^{a}\end{array}$ \\
\hline 1 & chr1:75198768-75199178 & 410 & 8 & $7.60 \times 10^{-6}$ & 0.001 & $\begin{array}{c}\text { CRYZ }(+119) / T Y W 3 \\
(+133)\end{array}$ \\
\hline 2 & chr7:3227262-3227333 & 71 & 3 & $9.01 \times 10^{-6}$ & 0.091 & $\begin{array}{c}\text { SDK1 } \\
(-113,782) / C A R D 11 \\
(-143,719)\end{array}$ \\
\hline 3 & chr3:138067848-138068014 & 166 & 6 & $3.07 \times 10^{-5}$ & 0.131 & $\begin{array}{c}\text { MRAS }(+1392) / E S Y T 3 \\
(-85,524)\end{array}$ \\
\hline 4 & chr15:93353059-93353199 & 140 & 3 & $7.35 \times 10^{-5}$ & 0.328 & $\begin{array}{c}\text { CHD2 } \\
(-89,929) / F A M 174 B \\
(-153,941)\end{array}$ \\
\hline 5 & chr19:17830341-17830453 & 112 & 3 & $7.61 \times 10^{-5}$ & 0.402 & MAP1S (+236) \\
\hline 6 & chr13:41635362-41635513 & 151 & 4 & $1.05 \times 10^{-4}$ & 0.409 & WBP4 (+28) \\
\hline 7 & chr8:1765217-1765388 & 171 & 7 & $1.54 \times 10^{-4}$ & 0.494 & $\begin{array}{c}\text { ARHGEF10 } \\
(-6839) / C L N 8 \\
(+53,375)\end{array}$ \\
\hline
\end{tabular}

The table shows the DMRs with a Šidák adjusted $p$-value $<0.5$, their length (in bp and number of CpG sites), significance and closest genes. $\mathrm{a},{ }^{\prime}+$ ' indicates that the DMR is downstream of the TSS, ' - ' indicates that the DMR is upstream of the TSS; SLK, Stouffer-Liptak-Kechris; adj, adjusted; TSS, transcription start site.

\section{Discussion}

In this study we have investigated genome-wide methylation patterns in 16 monozygotic twin pairs, of which eight were discordant and six concordant for TSD, while two pairs were asymptomatic. None of the investigated $\mathrm{CpG}$ sites reached a genome wide significance, but we identified nine CpG sites with suggestive significance $\left(p<1 \times 10^{-5}\right.$, Table 1) and seven DMRs (Šidák-corrected $p<0.5$, Table 3), which may be associated with TSD.

Of the nine DMPs with suggestive significance three were annotated to genes previously associated with neuropsychiatric disorders (TSC1, NEMF and ADA). NEMF (nuclear export mediator factor) encodes a component of the ribosome quality control complex and has previously been associated with ASD [17]. Furthermore, pathogenic variants of NEMF have been shown to cause neurodegeneration in mice [18]. ADA (adenosine deaminase) encodes a protein which is important for purine metabolism, and $A D A$ deficiency causes severe combined immunodeficiency (SCID). Reduced adenosine deaminase activity has been observed in ASD individuals [19] and a variant of the gene with low enzymatic activity has been associated with ASD [20].

Of the seven DMRs three were annotated to the regulatory regions of genes previously associated with neuropsychiatric disorders (SDK1, CHD2 and CLN8). SDK1 (The Sidekick Cell Adhesion Molecule 1) has been associated with ASD [21-24], and ADHD [25,26]; CHD2 (Chromodomain Helicase DNA Binding Protein 2) variants has been identified in individuals with central nervous system pathologies [27]; and CLN8 (the ceroid-lipofuscinosis, neuronal 8) has been linked to ASD through rare missense variants found in a Japanese family [28].

The DMP most significantly associated with TSD was within the promoter region of TSC1 coding for a subunit of the tuberous sclerosis complex (TSC). Pathogenic TSC1 variants lead to tuberous sclerosis, which is characterized by skin abnormalities, developmental delay, epilepsy and behavioural problems such as ADHD and ASD [29]. TSC1 and TSC2 together with TBC1D7 (TBC1 domain family, member 7) comprise the tuberous sclerosis protein complex which has crucial roles in cell growth. Notably, in a GWAS (genome-wide association study) meta-study investigating the shared common background of GTS and ADHD the top and third SNPs were annotated to TBC1D7 [30]. TSC1 regulates 
signalling of mTOR (mechanistic target of rapamycin) by the dual function of inhibiting the mTOR complex 1 and activating the mTOR complex 2 [31-33]. mTOR functions as a serine/threonine protein kinase which promotes synthesis of lipids, nucleotides and proteins, and it also comprises part of the larger PI3K/AKT/mTOR pathway, which is associated with neuropsychiatric disorders such as depression and ASD [34-36]. Disruption of mTOR signalling can affect neuronal growth and proliferation, as well as the release of dopamine [33,37], which has extensively been studied in GTS [38,39]. Altered mTOR signalling has also been associated with ASD, schizophrenia, depression and epilepsy [40-44]. An increased hazard ratio (HR) for epilepsy has been observed in children with GTS (adjusted HR $=16.27,95 \% \mathrm{CI}=6.26-18.46$ ), which may indicate a neurobiological overlap between TSD and epilepsy [45]. However, in another study a negative, though not significant, genetic correlation was found between GTS and epilepsy [46].

Genes involved in the phosphoinositide and the PTEN pathways, as well as insulin receptor substrate binding, was significantly enriched among the nominally significant DMPs $(p<0.01)$ we identified in this study (Table 2$)$. These pathways and cellular processes also constitute parts of the larger PI3K/AKT/mTOR pathway. SNPs located in the receptor tyrosine kinase gene FLT3, which is an activator of the PI3K/AKT/mTOR pathway [47], have been found in a GTS-pathway investigation and a GTS-GWAS [48,49]; and it was the only SNP reaching genome-wide significance in the latter study [49]. Furthermore, through exome sequencing of sporadic GTS individuals and their healthy parents, a likely pathogenic missense variant (rs140964083: G>A) was identified in RICTOR (rapamycininsensitive companion of mammalian target of rapamycin) encoding a component of the mTOR2 complex [50].

The top DMR in the present study was within the overlapping first exons of CRYZ (Crystallin Zeta) and TYW3 (TRNA-YW Synthesizing Protein 3 Homolog) which are transcribed from opposite strands. In a previous GWAS, a SNP near these two genes was significantly associated with resistin levels in blood and transcript levels of the gene encoding resistin in leukocytes [51]. Notably, increased resistin levels have been shown to activate mTOR signalling through phosphorylation of TSC2 [52].

In conclusion, the results of the present study and the findings from previous studies suggest that deregulation of the PI3K/AKT/mTOR pathway may be one of the contributing risk factors in TSD pathogenesis. Involvement of this pathway and particularly mTOR signalling are widely recognized as contributing factors to a broad range of neuropsychiatric disorders, which further support this hypothesis. As TSD is considered a multifactorial disease, the pathogenesis is likely to include a combination of genetic, epigenetic and environmental factors, and to consist of several pathways and cellular functions. However, further methylation studies using larger cohorts should be carried out to replicate the current findings, and expression studies of the components of the PI3K/AKT/mTOR pathway may give insights to the TSD pathogenesis.

The present study is the first to date epigenome-wide study of methylation changes in monozygotic twins with TSD. The relatively small sample size was a limitation, but the twin-based design offers unique advantages over the classic case-control setup even with a relatively small sample size. We carried out the methylation studies using peripheral blood, and it is possible that brain regions known to be involved in TSD pathology may show different methylation patterns to the ones we observed. Epigenomic studies of neuropsychiatric disorders have largely been carried out on peripheral blood, as brain tissue is not available. However, studies suggest that blood methylation can be informative for psychiatric conditions, as factors affecting the brain have been shown to leave biomarker signatures in the blood. Furthermore, one of the significant findings of the GTS-pathway study implicated involvement of lymphocytic pathways in GTS aetiology, which supports that blood can be used to identify methylation biomarkers.

Supplementary Materials: The following are available online at https:/ / www.mdpi.com/article/10 .3390/genes12101510/s1, Figure S1: Blood cell composition of samples, Table S1: Genes identified in the enrichment analysis. 
Author Contributions: Conceptualization, Z.T.; methodology, Q.T. and Z.T.; formal analysis, M.H.; investigation, M.H.; resources, A.S., N.M.D. and Z.T.; data curation, M.H., C.S.H. and J.B.-G.; writingoriginal draft preparation, M.H.; writing—review and editing, A.M.L., Q.T. and Z.T.; visualization, M.H.; supervision, Q.T. and Z.T.; project administration, Z.T.; funding acquisition, Z.T. All authors have read and agreed to the published version of the manuscript.

Funding: This research was funded by Lundbeck Fonden, grant number R100-2011-9332.

Institutional Review Board Statement: The study was conducted according to the guidelines of the Declaration of Helsinki and approved by the Danish Institutional Review Board (2011 H-2-2010-144. Date of approval: 3/3-2016).

Informed Consent Statement: Informed consent was obtained from all subjects involved in the study.

Data Availability Statement: The data presented in this study are available on request from the corresponding author.

Acknowledgments: We would like to thank Jette Bune Rasmussen for help with editing the figures.

Conflicts of Interest: The authors declare no conflict of interest. The funders had no role in the design of the study; in the collection, analyses, or interpretation of data; in the writing of the manuscript, or in the decision to publish the results.

\section{References}

1. Müller-Vahl, K.R.; Sambrani, T.; Jakubovski, E. Tic disorders revisited: Introduction of the term "tic spectrum disorders". Eur. Child Adolesc. Psychiatry 2019, 28, 1129-1135. [CrossRef] [PubMed]

2. Hirschtritt, M.E.; Lee, P.C.; Pauls, D.L.; Dion, Y.; Grados, M.A.; Illmann, C.; King, R.A.; Sandor, P.; McMahon, W.M.; Lyon, G.J.; et al. Lifetime prevalence, age of risk, and genetic relationships of comorbid psychiatric disorders in tourette syndrome. JAMA Psychiatry 2015, 72, 325-333. [CrossRef] [PubMed]

3. Burd, L.; Li, Q.; Kerbeshian, J.; Klug, M.G.; Freeman, R.D. Tourette syndrome and comorbid pervasive developmental disorders. J. Child Neurol. 2009, 24, 170-175. [CrossRef] [PubMed]

4. $\quad$ Mataix-Cols, D.; Isomura, K.; Pérez-Vigil, A.; Chang, Z.; Rück, C.; Johan Larsson, K.; Leckman, J.F.; Serlachius, E.; Larsson, H.; Lichtenstein, P. Familial risks of tourette syndrome and chronic tic disorders a population-based cohort study. JAMA Psychiatry 2015, 72, 787-793. [CrossRef]

5. Davis, L.K.; Yu, D.; Keenan, C.L.; Gamazon, E.R.; Konkashbaev, A.I.; Derks, E.M.; Neale, B.M.; Yang, J.; Lee, S.H.; Evans, P.; et al. Partitioning the Heritability of Tourette Syndrome and Obsessive Compulsive Disorder Reveals Differences in Genetic Architecture. PLoS Genet. 2013, 9, e1003864. [CrossRef] [PubMed]

6. $\quad$ Bertelsen, B.; Melchior, L.; Jensen, L.R.; Groth, C.; Glenthøj, B.; Rizzo, R.; Debes, N.M.; Skov, L.; Brøndum-Nielsen, K.; Paschou, P.; et al. Intragenic deletions affecting two alternative transcripts of the IMMP2L gene in patients with Tourette syndrome. Eur. J. Hum. Genet. 2014, 22, 1283-1289. [CrossRef] [PubMed]

7. Bertelsen, B.; Stefánsson, H.; Riff Jensen, L.; Melchior, L.; Mol Debes, N.; Groth, C.; Skov, L.; Werge, T.; Karagiannidis, I.; Tarnok, Z.; et al. Association of AADAC Deletion and Gilles de la Tourette Syndrome in a Large European Cohort. Biol. Psychiatry 2016, 79, 383-391. [CrossRef]

8. Huang, A.Y.; Yu, D.; Davis, L.K.; Sul, J.H.; Tsetsos, F.; Ramensky, V.; Zelaya, I.; Ramos, E.M.; Osiecki, L.; Chen, J.A.; et al. Rare Copy Number Variants in NRXN1 and CNTN6 Increase Risk for Tourette Syndrome. Neuron 2017, 94, 1101-1111.e7. [CrossRef]

9. Müller-Vahl, K.R.; Loeber, G.; Kotsiari, A.; Müller-Engling, L.; Frieling, H. Gilles de la Tourette syndrome is associated with hypermethylation of the dopamine D2 receptor gene. J. Psychiatr. Res. 2017, 86, 1-8. [CrossRef] [PubMed]

10. Hildonen, M.; Levy, A.M.; Dahl, C.; Bjerregaard, V.A.; Møller, L.B.; Guldberg, P.; Debes, N.M.; Tümer, Z. Elevated expression of SLC6A4 encoding the serotonin transporter (SERT) in gilles de la tourette syndrome. Genes 2021, 12, 86. [CrossRef]

11. Tan, Q.; Christiansen, L.; Von Bornemann Hjelmborg, J.; Christensen, K. Twin methodology in epigenetic studies. J. Exp. Biol. 2015, 218, 134-139. [CrossRef]

12. Zilhão, N.R.; Padmanabhuni, S.S.; Pagliaroli, L.; Barta, C.; Smit, D.J.A.; Cath, D.; Nivard, M.G.; Baselmans, B.M.L.; Van Dongen, J.; Paschou, P.; et al. Epigenome-Wide Association Study of Tic Disorders. Twin Res. Hum. Genet. 2015, 18, 699-709. [CrossRef]

13. Aryee, M.J.; Jaffe, A.E.; Corrada-Bravo, H.; Ladd-Acosta, C.; Feinberg, A.P.; Hansen, K.D.; Irizarry, R.A. Minfi: A flexible and comprehensive Bioconductor package for the analysis of Infinium DNA methylation microarrays. Bioinformatics 2014, 30, 1363-1369. [CrossRef]

14. Salas, L.A.; Koestler, D.C.; Butler, R.A.; Hansen, H.M.; Wiencke, J.K.; Kelsey, K.T.; Christensen, B.C. FlowSorted.Blood.EPIC. DIM 2018, 575719, 289.

15. Kuznetsova, A.; Brockhoff, P.B.; Christensen, R.H.B. lmerTest Package: Tests in Linear Mixed Effects Models. J. Stat. Softw. 2017, 82, 1-26. [CrossRef]

16. Pedersen, B.S.; Schwartz, D.A.; Yang, I.V.; Kechris, K.J. Comb-p: Software for combining, analyzing, grouping and correcting spatially correlated P-values. Bioinformatics 2012, 28, 2986-2988. [CrossRef] 
17. Stessman, H.A.F.; Xiong, B.; Coe, B.P.; Wang, T.; Hoekzema, K.; Fenckova, M.; Kvarnung, M.; Gerdts, J.; Trinh, S.; Cosemans, N.; et al. Targeted sequencing identifies 91 neurodevelopmental-disorder risk genes with autism and developmental-disability biases. Nat. Genet. 2017, 49, 515-526. [CrossRef] [PubMed]

18. Martin, P.B.; Kigoshi-Tansho, Y.; Sher, R.B.; Ravenscroft, G.; Stauffer, J.E.; Kumar, R.; Yonashiro, R.; Müller, T.; Griffith, C.; Allen, W.; et al. NEMF mutations that impair ribosome-associated quality control are associated with neuromuscular disease. Nat. Commun. 2020, 1, 1-12. [CrossRef]

19. Stubbs, G.; Litt, M.; Lis, E.; Jackson, R.; Voth, W.; Lindberg, A.; Litt, R. Adenosine Deaminase Activity Decreased in Autism. J. Am. Acad. Child Psychiatry 1982, 21, 71-74. [CrossRef] [PubMed]

20. Bottini, N.; De Luca, D.; Saccucci, P.; Fiumara, A.; Elia, M.; Porfirio, M.C.; Lucarelli, P.; Curatolo, P. Autism: Evidence of association with adenosine deaminase genetic polymorphism. Neurogenetics 2001, 3, 111-113. [CrossRef] [PubMed]

21. Guo, H.; Duyzend, M.H.; Coe, B.P.; Baker, C.; Hoekzema, K.; Gerdts, J.; Turner, T.N.; Zody, M.C.; Beighley, J.S.; Murali, S.C.; et al. Genome sequencing identifies multiple deleterious variants in autism patients with more severe phenotypes. Genet. Med. 2019, 21, 1611-1620. [CrossRef] [PubMed]

22. Connolly, J.J.; Glessner, J.T.; Hakonarson, H. A Genome-Wide Association Study of Autism Incorporating Autism Diagnostic Interview-Revised, Autism Diagnostic Observation Schedule, and Social Responsiveness Scale. Child Dev. 2013, 84, 17-33. [CrossRef] [PubMed]

23. Narita, A.; Nagai, M.; Mizuno, S.; Ogishima, S.; Tamiya, G.; Ueki, M.; Sakurai, R.; Makino, S.; Obara, T.; Ishikuro, M.; et al. Clustering by phenotype and genome-wide association study in autism. Transl. Psychiatry 2020, 10, 1-12. [CrossRef] [PubMed]

24. Tsang, K.M.; Croen, L.A.; Torres, A.R.; Kharrazi, M.; Delorenze, G.N.; Windham, G.C.; Yoshida, C.K.; Zerbo, O.; Weiss, L.A. A Genome-Wide Survey of Transgenerational Genetic Effects in Autism. PLoS ONE 2013, 8, e76978. [CrossRef]

25. Elia, J.; Gai, X.; Xie, H.M.; Perin, J.C.; Geiger, E.; Glessner, J.T.; D’Arcy, M.; Deberardinis, R.; Frackelton, E.; Kim, C.; et al. Rare structural variants found in attention-deficit hyperactivity disorder are preferentially associated with neurodevelopmental genes. Mol. Psychiatry 2010, 15, 637-646. [CrossRef]

26. De Araújo Lima, L.; Feio-Dos-Santos, A.C.; Belangero, S.I.; Gadelha, A.; Bressan, R.A.; Salum, G.A.; Pan, P.M.; Moriyama, T.S.; Graeff-Martins, A.S.; Tamanaha, A.C.; et al. An integrative approach to investigate the respective roles of single-nucleotide variants and copy-number variants in Attention-Deficit/Hyperactivity Disorder. Sci. Rep. 2016, 6, 22851. [CrossRef]

27. Wilson, M.M.; Henshall, D.C.; Byrne, S.M.; Brennan, G.P. Chd2-related cns pathologies. Int. J. Mol. Sci. 2021, 22, 588. [CrossRef]

28. Egawa, J.; Watanabe, Y.; Wang, C.; Inoue, E.; Sugimoto, A.; Sugiyama, T.; Igeta, H.; Nunokawa, A.; Shibuya, M.; Kushima, I.; et al. Novel rare missense variations and risk of autism spectrum disorder: Whole-exome sequencing in two families with affected siblings and a two-stage follow-up study in a Japanese population. PLoS ONE 2015, 10, e0119413. [CrossRef]

29. de Vries, P.J.; Belousova, E.; Benedik, M.P.; Carter, T.; Cottin, V.; Curatolo, P.; Dahlin, M.; D'Amato, L.; Beaure d'Augères, G.; Ferreira, J.C.; et al. Tuberous Sclerosis Complex-Associated Neuropsychiatric Disorders (TAND): New Findings on Age, Sex, and Genotype in Relation to Intellectual Phenotype. Front. Neurol. 2020, 11, 603. [CrossRef]

30. Tsetsos, F.; Padmanabhuni, S.S.; Alexander, J.; Karagiannidis, I.; Tsifintaris, M.; Topaloudi, A.; Mantzaris, D.; Georgitsi, M.; Drineas, P.; Paschou, P. Meta-analysis of tourette syndrome and attention deficit hyperactivity disorder provides support for a shared genetic basis. Front. Neurosci. 2016, 10, 340. [CrossRef]

31. Huang, J.; Dibble, C.C.; Matsuzaki, M.; Manning, B.D. The TSC1-TSC2 Complex Is Required for Proper Activation of mTOR Complex 2. Mol. Cell. Biol. 2008, 28, 4104-4115. [CrossRef]

32. Shi, Q.; Saifetiarova, J.; Taylor, A.M.; Bhat, M.A. mTORC1 activation by loss of Tsc1 in myelinating glia causes downregulation of quaking and neurofascin 155 leading to paranodal domain disorganization. Front. Cell. Neurosci. 2018, 12, 201. [CrossRef]

33. Kosillo, P.; Doig, N.M.; Ahmed, K.M.; Agopyan-Miu, A.H.C.W.; Wong, C.D.; Conyers, L.; Threlfell, S.; Magill, P.J.; Bateup, H.S. Tsc1-mTORC1 signaling controls striatal dopamine release and cognitive flexibility. Nat. Commun. 2019, 10, 1-19. [CrossRef]

34. Kitagishi, Y.; Kobayashi, M.; Kikuta, K.; Matsuda, S. Roles of PI3K/AKT/GSK3/mTOR pathway in cell signaling of mental illnesses. Depress. Res. Treat. 2012, 2012, 752563. [CrossRef]

35. Sharma, A.; Mehan, S. Targeting PI3K-AKT/mTOR signaling in the prevention of autism. Neurochem. Int. 2021, $147,105067$. [CrossRef]

36. Matsuda, S.; Ikeda, Y.; Murakami, M.; Nakagawa, Y.; Tsuji, A.; Kitagishi, Y. Roles of PI3K/AKT/GSK3 Pathway Involved in Psychiatric Illnesses. Diseases 2019, 7, 22. [CrossRef] [PubMed]

37. Liu, X.; Li, Y.; Yu, L.; Vickstrom, C.R.; Liu, Q.S. VTA mTOR Signaling Regulates Dopamine Dynamics, Cocaine-Induced Synaptic Alterations, and Reward. Neuropsychopharmacology 2018, 43, 1066-1077. [CrossRef]

38. Buse, J.; Schoenefeld, K.; Münchau, A.; Roessner, V. Neuromodulation in Tourette syndrome: Dopamine and beyond. Neurosci. Biobehav. Rev. 2013, 37, 1069-1084. [CrossRef] [PubMed]

39. Maia, T.V.; Conceição, V.A. Dopaminergic Disturbances in Tourette Syndrome: An Integrative Account. Biol. Psychiatry 2018, 84, 332-344. [CrossRef] [PubMed]

40. Ganesan, H.; Balasubramanian, V.; Iyer, M.; Venugopal, A.; Subramaniam, M.D.; Cho, S.G.; Vellingiri, B. mTOR signalling pathway-A root cause for idiopathic autism? BMB Rep. 2019, 52, 424-433. [CrossRef] [PubMed]

41. Gururajan, A.; Van Den Buuse, M. Is the mTOR-signalling cascade disrupted in Schizophrenia? J. Neurochem. 2014, 129, 377-387. [CrossRef] 
42. Chadha, R.; Meador-Woodruff, J.H. Downregulated AKT-mTOR signaling pathway proteins in dorsolateral prefrontal cortex in Schizophrenia. Neuropsychopharmacology 2020, 45, 1059-1067. [CrossRef] [PubMed]

43. Abelaira, H.M.; Réus, G.Z.; Neotti, M.V.; Quevedo, J. The role of mTOR in depression and antidepressant responses. Life Sci. 2014, 101, 10-14. [CrossRef] [PubMed]

44. Meng, X.F.; Yu, J.T.; Song, J.H.; Chi, S.; Tan, L. Role of the mTOR signaling pathway in epilepsy. J. Neurol. Sci. 2013, $332,4-15$. [CrossRef] [PubMed]

45. Wong, L.C.; Huang, H.L.; Weng, W.C.; Jong, Y.J.; Yin, Y.J.; Chen, H.A.; Lee, W.T.; Ho, S.Y. Increased risk of epilepsy in children with Tourette syndrome: A population-based case-control study. Res. Dev. Disabil. 2016, 51-52, 181-187. [CrossRef]

46. Anttila, V.; Bulik-Sullivan, B.; Finucane, H.K.; Walters, R.K.; Bras, J.; Duncan, L.; Escott-Price, V.; Falcone, G.J.; Gormley, P.; Malik, R.; et al. Analysis of shared heritability in common disorders of the brain. Science 2018, 360, eaap8757. [CrossRef]

47. Chen, W.; Drakos, E.; Grammatikakis, I.; Schlette, E.J.; Li, J.; Leventaki, V.; Staikou-Drakopoulou, E.; Patsouris, E.; Panayiotidis, P.; Medeiros, L.J.; et al. MTOR signaling is activated by FLT3 kinase and promotes survival of FLT3-mutated acute myeloid leukemia cells. Mol. Cancer 2010, 9, 292. [CrossRef]

48. Tsetsos, F.; Yu, D.; Sul, J.H.; Huang, A.Y.; Illmann, C.; Osiecki, L.; Darrow, S.M.; Hirschtritt, M.E.; Greenberg, E.; Muller-Vahl, K.R.; et al. Synaptic processes and immune-related pathways implicated in Tourette syndrome. Transl. Psychiatry 2021, 11, 1-12. [CrossRef]

49. Yu, D.; Sul, J.H.; Tsetsos, F.; Nawaz, M.S.; Huang, A.Y.; Zelaya, I.; Illmann, C.; Osiecki, L.; Darrow, S.M.; Hirschtritt, M.E.; et al. Interrogating the genetic determinants of Tourette's syndrome and other tiC disorders through genome-wide association studies. Am. J. Psychiatry 2019, 176, 217-227. [CrossRef]

50. Eriguchi, Y.; Kuwabara, H.; Inai, A.; Kawakubo, Y.; Nishimura, F.; Kakiuchi, C.; Tochigi, M.; Ohashi, J.; Aoki, N.; Kato, K.; et al. Identification of candidate genes involved in the etiology of sporadic Tourette syndrome by exome sequencing. Am. J. Med. Genet. Part B Neuropsychiatr. Genet. 2017, 174, 712-723. [CrossRef]

51. Qi, Q.; Menzaghi, C.; Smith, S.; Liang, L.; de Rekeneire, N.; Garcia, M.E.; Lohman, K.K.; Miljkovic, I.; Strotmeyer, E.S.; Cummings, S.R.; et al. Genome-wide association analysis identifies TYW3/CRYZ and NDST4 loci associated with circulating resistin levels. Hum. Mol. Genet. 2012, 21, 4774-4780. [CrossRef]

52. Kang, S.; Chemaly, E.R.; Hajjar, R.J.; Lebeche, D. Resistin promotes cardiac hypertrophy via the AMP-activated protein kinase/mammalian target of rapamycin (AMPK/mTOR) and c-Jun N-terminal kinase/insulin receptor substrate 1 (JNK/IRS1) pathways. J. Biol. Chem. 2011, 286, 18465-18473. [CrossRef] 